\title{
THE AMERICAN WOODCOCK IN MANITOBA
}

ROBERT W. NERO, Department of Renewable Resources and Transportation Services, 1495 St. James Street, Winnipeg, Manitoba. R3H OW9

The American Woodcock has been recognized as a breeding bird in extreme southeastern Manitoba since 1886. 1310485155 The most recently published account shows this distribution fairly well (see Fig. 1).46 Because the woodcock is mainly crepuscular, it has been observed in this province by relatively few persons.

This woodland-nesting shorebird, with its stout body, large head and short neck, relatively short legs and long bill, is readily recognized when seen on the ground or in flight. It tends to sit close and flush at the last moment, rising upwards on short wings that make a distinctive sound. The males have a harsh, penetrating call given while on the ground - a sharp, nasal "peent". The call is rarely heard during daylight hours, but early in the morning, late in the evening and at night, the characteristic "peent" permits immediate identification. The male also has a complex aerial flight accompanied by both vocalizations ("chirping") and mechanical sounds ("twittering") produced by its three vibrating outer primaries. The male's spectacular courtship display is usually performed about half an hour after sunset, in the equally dim light before dawn and on moonlit nights.

In eastern Canada and the United States the woodcock is plentiful and is a popular game bird. In 1975, for example, 130,898 woodcock were taken by hunters in Canada, 65,469 being harvested in Ontario. ${ }^{4}$ The annual continental kill at times reaches one and a half million birds and is increasing. ${ }^{46}$ In Manitoba, however, the bird is at the Westernmost part of its breeding range and occurs in relatively limited numbers. Little information is available on its status or population since it has not been the subject of any official investigation by provincial wildlife authorities. In 1876 it was protected in Manitoba from May 25 to August $15^{9}$ but this merely represented the broad application of a protective attitude in Canada, without reference to local occurrence of the species.

\section{Earlier Observations}

The earliest Manitoba record appears to be that of Thomas Palliser who shot two woodcock on July 23, 1857, presumably at Marion Lake, an oxbow of the Red River south of St. Jean Baptiste. He noted as follows: "... we stopped for dinner at a lake which has been, at one time, a bend of the river, but which is now converted into a lagoon ... while here, we shot a brace of woodcocks in some alders which skirt the lake. This bird, although very common in Canada (bear in mind the date and locality), is said to be only a rare visitor. in this quarter. ${ }^{\prime 47}$

Thompson (Seton) reported the following for this species: "Very rare summer resident. Winnipeg: rare; only two pairs killed, and under a dozen birds seen altogether in 4 years (Hine). I saw one specimen of the woodcock (quoting Bell) at York Factory, in the end of August last (1879). This bird is not uncommon in Manitoba, although the fact is not generally known (Bell, 1880). Oak Point: 1885, first seen May 13; rare; one was shot (Small). Rare summer resident; I shot ten birds (quoting Nash) in 5 years near Portage la Prairie; in 1886 I found a pair breeding near Winnipeg; arrive about the end of April, depart in September (Nash). ${ }^{11} 55$

Wallis flushed a woodcock near Westbourne on August 10, 1908; F. Rhind, Westbourne, told him that 20 years earlier (1888?) a number had been shot at the same spot. Rhind also said that in 1902 or 1903 wood- 
cock were "very plentiful" on ranchland on the southwest shore of Lake Manitoba. ${ }^{58}$

A. G. Lawrence, a Winnipeg naturalist, went to considerable efforts to solicit records through his enthusiastic and knowledgeable accounts of birds in a nature column in a Winnipeg newpaper. Upon receiving his second report of a woodcock sighting in 1928 he made a special attempt to arouse an interest in this species. His columns record observations of woodcock for 16 out of 28 years in the period 1923 to 1950 . Of 30 reports during this period, 19 were for eight years, from 1931 to 1938, when the bird seemed more abundant than usual. Half of the 30 reports were for Winnipeg (and suburbs), suggesting the occurrence, as so often mentioned in his column, of a local breeding population (or possible an increase in the provincial population?). He gives two general accounts that are of particular interest. In his 368 th column, ${ }^{15}$ Lawrence reported as follows:

"A record of unusual interest comes from A. Mount, North Kildonan, Man., who states that on March 19 (1928) a Woodcock flew up from near the creek on Lot 54, passing above his head and giving him an excellent view of its characteristic build and markings. Mr. Mount states that he has seen a Woodcock frequently during the past two summers $(1926,1927)$ in the same vicinity, the bird generally flying at dusk from the woods by the creek to a bluff some distance away...

"Southern Manitoba is about the northern and western limits of the Woodcock's range and consequently records of its occurrence here are scarce. There are old authentic reports of birds taken at Winnipeg, Portage la Prairie, Oak Point, Stuartburn and Cooks Creek, south of Tysdall, the latter a record of ex-sheriff Collin Inkster who shot a young one in September 1879 or 1880 . Dr. R. Bell of the Canadian Geological Survey, saw a single bird at York Factory, Hudson Bay, in August 1879, apparently a straggler. N. Criddle, Treesbank, Man., informs us that the bird is rare there, he having seen about five Woodcock in thirty years, the latest fully a dozen years ago. The most recent report we have is that of $R$. D. Bird who saw a Woodcock in Assiniboine Park, Winnipeg, on October 7, 1923.
"From 1920 to 1923 a number of hunters reported to the Provincial Game Department that they had shot Woodcock, 58 in four years, but as the Wilson Snipe is constantly confused with the Woodcock, little reliance can be placed on this figure, though there is a possibility that some of the birds were Woodcocks."

Later he added"9: "The American Woodcock is of particular interest to Winnipeg ornithologists as, in spite of its being believed to breed in or near the North Kildonan Bird Sanctuary, it has for ten years outwitted the birdmen and the first nest for Manitoba has yet to be recorded. The birds were seen in this area in subsequent summers (since 1928) by H. D. Whellams, A. B. Gresham, and others, but we were not among the favored few.

"While these North Kildonan records are the only spring reports of Woodcock, hence their unusual interest, the bird has been seen and reported in 'Chickadee Notes' nearly every fall since 1928 in other areas near the city and at other points in southern Manitoba in both spring and fall. Around Winnipeg, the birds have been observed in St. Vital (A. W. Murdoch); St. James Park, Winnipeg (Dr. H. M. Speechly); St. James (Major J. P. Oliver, C. L. Broley); Bird's Hill (a wounded bird brought to the Free Press by an unknown reader); Elmwood Park, Winnipeg (G. Ferris); and in Tuxedo from August 25 to 29, 1936, by Allan Morrison.

"Mrs. J. R. Glassey, St. James now reports to Professor V. W. Jackson that a Woodcock was in their garden last summer (1936) from July 19 to 30 and again from August 24 onwards for some time."

Despite these early reports of the woodcock in southeastern Manitoba, and Lawrence's many records, the status of the species has remained, in the viewpoint of most birders, essentially unknown, Lawrence himself, for example, said: "it is so rare here (southeastern Manitoba) that an observation deserves a headline." Shortt considered an injured woodcock found in Winnipeg "a notable addition to Manitoba's bird records." 52 Referring to a Stonewall record of April 29, 1966, the late Harold Mossop reported: "Although I have been birding for well over half a century (in Manitoba), I have seen just two of these extremely interesting birds in the wild". ${ }^{41}$ In the same column, however, Mossop 


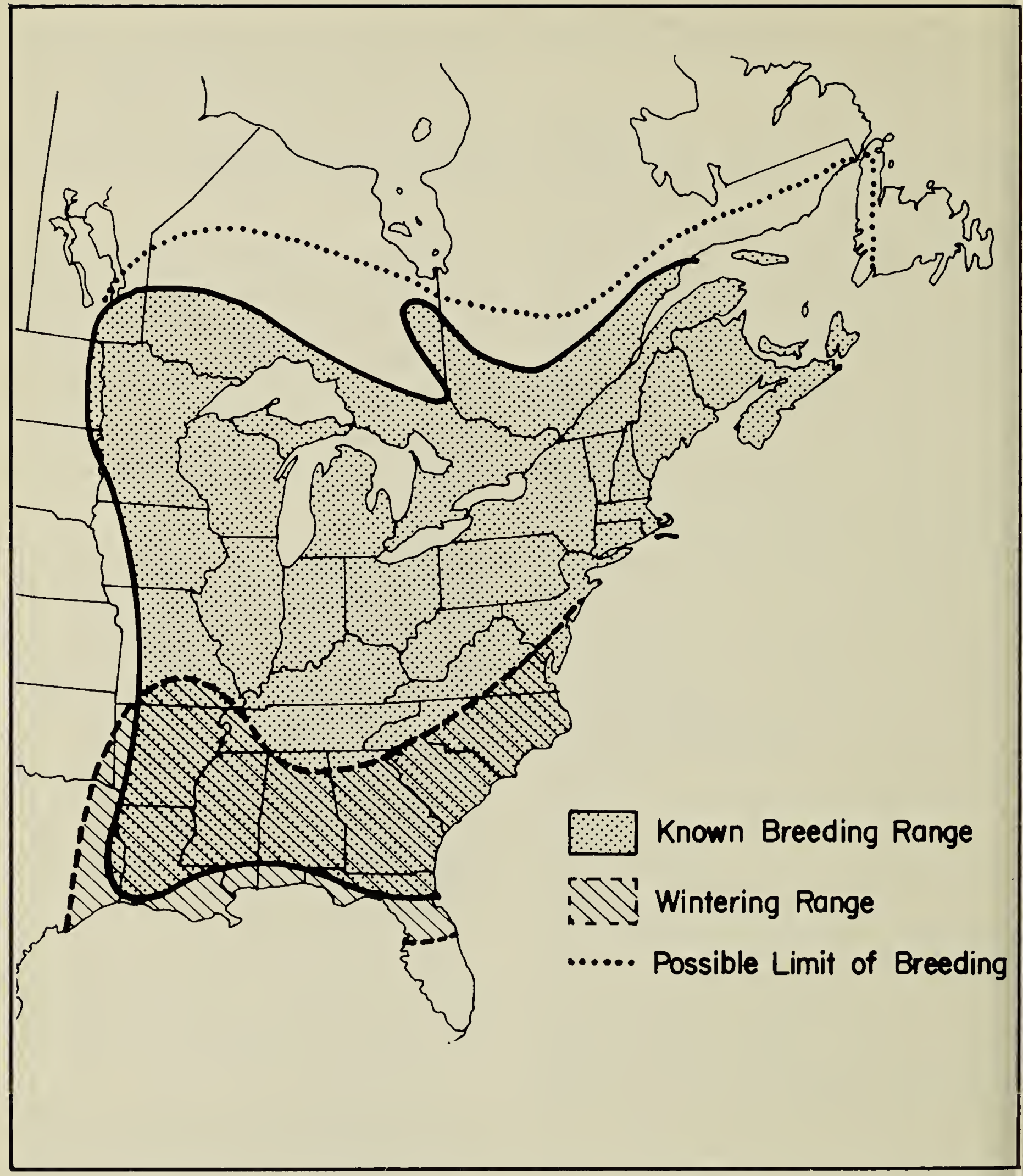

Fig. 1 Woodcock breeding and wintering ranges in North America (after Owen, 1977).46

added: "Perhaps they're not so rare here as supposed. Being so well camouflaged as they sleep all day, perhaps we're just overlooking them." Notwithstanding this perceptive comment, and although born and raised near Winnipeg, Gardner went so far as to state: "it is not recorded every year in this province. ${ }^{1 / 8}$

\section{Recent Observations}

Observations made by myself and others in recent years show that the
American Woodcock continues to flourish in Manitoba, annually returning to occupy certain sites and occasionally appearing temporarily in new areas. It regularly occurs in a limited area of extreme southeastern Manitoba as a fairly abundant resident and may occupy a larger breeding range than is now known.

My first observations of Woodcock in Manitoba were made during my second year of residence here when 
two single birds were seen in August and September, 1967, about 30 and 50 miles respectively east of Winnipeg. One flushed at my feet at midday, the other flew across a road in front of my car at dusk. Not since I had made "peenting counts" as a graduate student and hunted them years ago in Wisconsin had I seen a woodcock. I next observed a woodcock on April 25,1970 , when, in company with Robert Taylor and Gordon Graham, a bird, suspected to be a breeder, was flushed from a wooded area at Piney (see under "Breeding Evidence"). A year later, Herb Copland and I stopped late in the evening of April 9, 1971 at East Braintree to listen for Great Gray Owls; as soon as I rolled my window down I heard the peent of a woodcock. We stayed long enough to distinguish four peenting birds and watched them display overhead in the fading light.

Thereafter, my colleagues and I took a special interest in woodcock, stopping to listen for them in likely spots whenever there was opportunity. Because most of our time was spent searching for Great Gray Owls, only limited time was given to this activity. Also, because our efforts to find owls was largely confined to the wooded region south of Lake Winnipeg and east of the Red River valley (south into northern Minnesota), most of our experience with woodcock relates to this area.

Between 1971 and 1977 we observed woodcock regularly at nearly a dozen sites between Lac du Bonnet and Piney (see Fig. 2). Numbers of displaying birds at these sites ranges from 5 to 20 or more. Because birds were present in these specific areas every year during the breeding season they were assumed to be breeding.

The nearest breeding site to Winnipeg known to us was between Anola and Vivian on Provincial Road 15 , about 20 miles east of the Red River Floodway. We introduced a number of birders to woodcock by leading or directing them to this particular site. Efforts to find birds in similar habitat at other sites, for exam- ple, south to the TransCanada Highway, in the vicinity of Steinbach, and southeast along Provincial Trunk Highway 12, were unsuccessful. Many times we attempted to find birds in what appeared to be suitable habitat adjacent to known breeding grounds, again with little success. We concluded that although woodcock were widely scattered across extreme southeastern Manitoba, they occurred in restricted localities, separated by large, unoccupied areas. Nevertheless, we recognized that with more time and effort, woodcock would probably be found in many additional places within this general area.

A growing impression that woodcock were restricted in breeding range to the area east of Winnipeg was abruptly changed in 1974, when graduate student Tim Sopuck discovered five birds, apparently on territory, 12 miles west of Hodgson and about 85 miles north-northwest of Winnipeg. Woodcock were observed peenting and giving aerial displays every night from about May 31 through the first week of June, 1974 (pers. comm., 1974). Tape recordings made at the site by Terry Dick, University of Manitoba, were readily identified as woodcock by Herb Copland (pers. corres., 1974). The area, which lies just outside the southeast corner of the Mantagao Wildlife Management Area, consisted of low land covered with alder and pastured, young aspen poplar stands. The number of birds, constancy of peenting and aerial displays, and period of activity, indicates breeding.

Additional breeding in the Interlake is strongly supported by observations of fall migrants at Sandridge, about 45 miles north of Winnipeg. Don W. Simkin, Toronto, Ontario, reported (pers. corres., 1977) as follows:

"Two of us, using pointing dogs, hunted the shoreline of the large slough just north of the hamlet of Dennis Lake and just east of Sandridge for about 3 hours on October 5 (1976). Our quarry was non-mallard ducks and any snipe and ruffed grouse which we might encounter. 


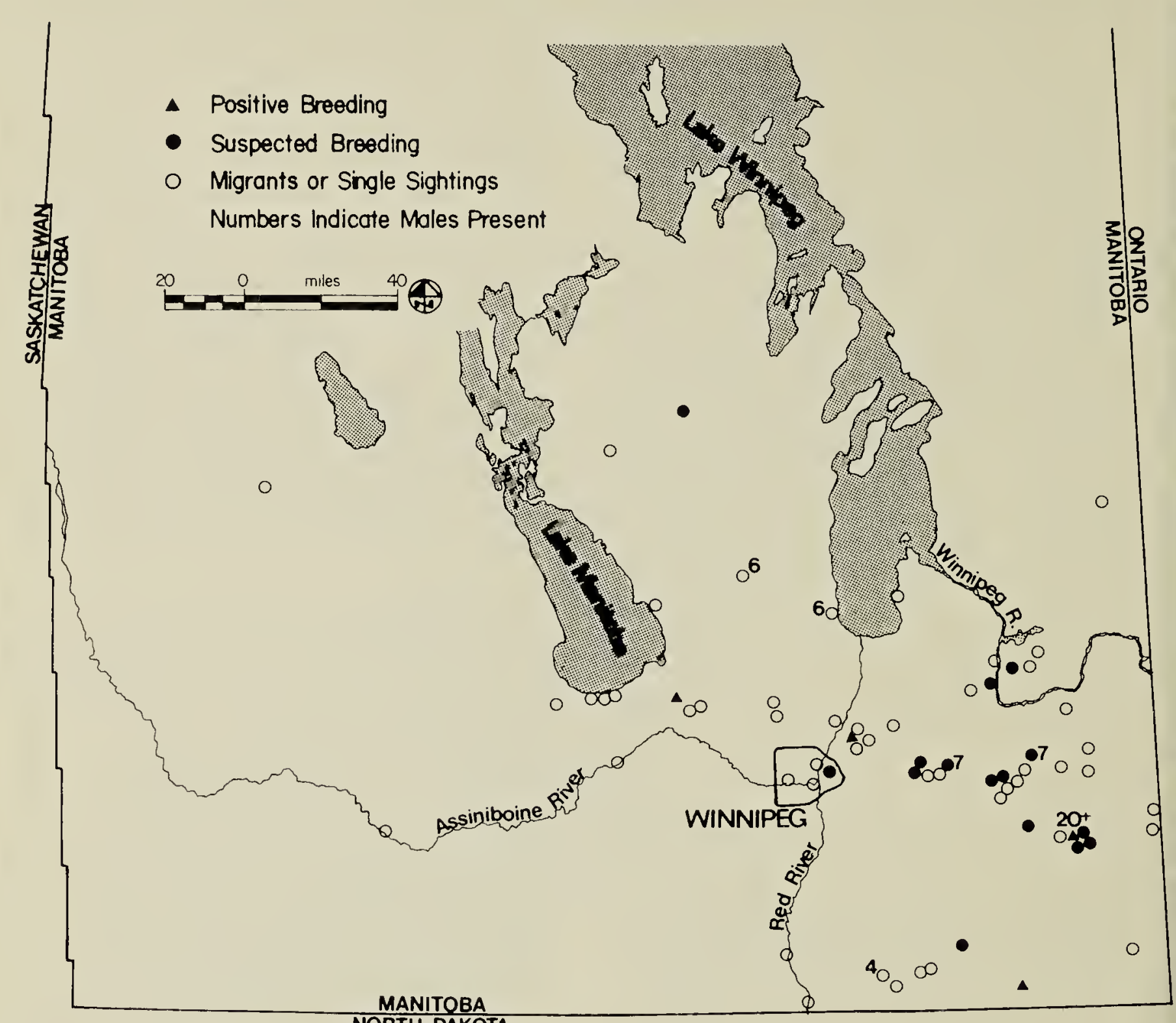

Fig. 2 Manitoba Woodcock locality records 1857-1977.

"The habitat which we hunted was quite similar to cover which we most frequently hunt for woodcock in Ontario - namely, pole-sized aspen with a slightly damp organic soil base.

"During the period that we hunted each on opposite sides of the rather large body of shallow water (the extreme southwest end) - we flushed at least 6 woodcock - 3 each - and, on average, reflushed them at least once. For each woodcock flushed, we probably put up 6 snipe. The snipe were located in the fresher areas immediately adjacent to the open marsh.

"Although I have hunted in the interlake country on two other one-week trips - mainly in the GypsumvilleWaterhen Lake area, this is the first time that I have put up any woodcock. It probably is worth noting, however, that the cover we hunted on the day we en- countered woodcock was the only cover where, before going into it, one got the feeling he was going into woodcock habitat according to our Ontario conditioning."

The occurrence of woodcock north of Whiteshell Provincial Park, in the newly established Nopiming Provincial Park, has recently been documented by Calvin Cuthbert (pers. comm., 1977).

"A single bird was heard 'peenting' and observed engaged in its aerial courtship display during the late evening of May 11, 1977 and again early the following morning at Long Lake, approximately 28 miles southeast of Bissett. This is typical preCambrian Shield country with jack pine on many rock ridges and white spruce and 
aspen throughout much of the lower, richer soil areas. A number of summer cottages are situated at Long Lake and it was here the woodcock was observed. Its habitat consisted of a small, low-lying area throughout which willow clumps and aspen grew intermittently. This area was surrounded with rock. It was presumably either a migrant or encountered a mishap as it was not heard or seen again after the morning of May 12, despite numerous attempts to relocate it. The bird was seen by Bill Koonz, Nick Foy and myself."

\section{Breeding Evidence}

Under breeding range, Bent makes two references to Manitoba as follows: "North to southern Manitoba (Brandon, Portage la Prairie, and Winnipeg) ... West to ... southern Manitoba (Portage la Prairie). ${ }^{\prime \prime 3}$ The reference to Brandon is likely based on Criddle's records (five in 30 years, the latest around 1916; presumably migrants about 18 miles southeast of Treesbank. Similarly, Portage la Prairie was evidently chosen in relation to Wallis' Westbourne record ( 14 miles NW). Neither records supply an indication, however, of breeding status. The earliest basis for giving the species breeding status in the province appears to be the observation by $C$. W. Nash of "a pair breeding near Winnipeg" in 1886.55 Unfortunately, no further information is available for this suggestive report. The "young" woodcock reported shot by Inkster near Cooks Creek in September 1879 or 1880 , and later mounted, was presumably an immature bird, but it is not known how this age determination was made. In any case, an immature bird with full flight capability (this would have to be the case by September) would not necessarily have been raised in that vicinity. J. M. Waddell, who reported four birds on May 30,1928, southeast of Stuartburn, believed that they were breeding in that area. ${ }^{16}$

The almost annual occurrence of birds in spring and summer in the North Kildonan Bird Sanctuary from 1926 to 1937 , led to a general supposition that they were breeding in that area. ${ }^{15} 16$ As noted by Lawrence ${ }^{29}$ :
"Suffice it to say that the occurrence of so many Woodcock around Winnipeg in fall indicates that a nesting haunt must be in this vicinity; who will solve this nesting problem?" On May 22, 1949, in St. Vital, a freshly killed female woodcock was found; the "largest yolk (sic) in the ovary (was) about an eighth of an inch in diameter indicating, we believe, that the bird had laid its eggs" ${ }^{\prime \prime 37}$

The rather regular occurrence of small populations in southeastern Manitoba led Godfrey to assume that the woodcock was a breeding resident. ${ }^{10}$ He notes that a freshly laid egg found in 1970 is the "most definite evidence of nesting of which I am aware" (pers. corres., 1970). The details of the circumstances under which the egg was found follow: On April 20, 1970, Gordon G. Graham, Conservation Officer, found an egg resting on top of fresh snow near the edge of a woods adjacent to the C.O. residence at Piney. A pair of woodcocks had been seen nearby at the same time. A two-inch accumulation of snow which fell on April 18 and 19 presumably interrupted nesting, leading to the laying of the egg on the snow. Robert Taylor and I visited the area on April 25, obtained the egg (now in the collections of the Manitoba Museum of Man and Nature), and together with Graham, flushed a woodcock from the same area. This was a flooded hummocky woods. Evidently the birds were feeding on the exposed tops of the loamy hummocks. Woodcock were observed in this same locality in several successive years.

Following the above discovery, I made efforts over the next few years to find a nest. On several occasions I searched areas where woodcock regularly occurred, at times using a springer spaniel, but without success. As noted by Sheldon, however, "finding nests or young birds (of woodcock) is a matter of chance", the female sitting close on the nest and being well camouflaged. ${ }^{57}$

A road-killed female woodcock found on April 17, 1974 near Vita by $\mathrm{N}$. Foy was clearly in breeding condi- 


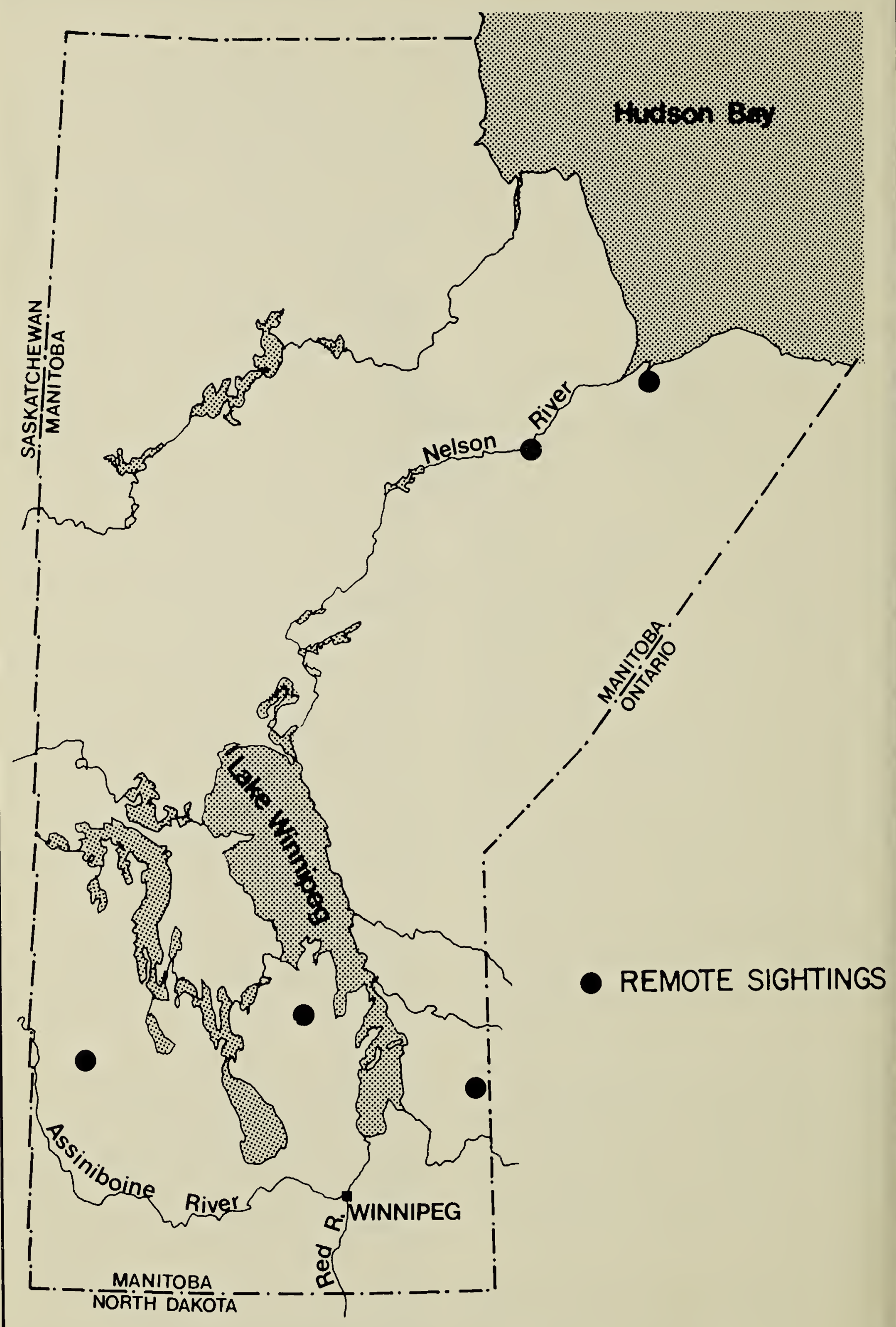

Fig. 3. Extreme northern woodcock records and more remote records for southern Manitoba. 
tion; it had an enlarged oviduct and the largest follicle was $8 \mathrm{~mm}$. in diameter; the bird weighed 168.5 grams (pers. corres., S. G. Sealy, 1977).

In 1975, a brood of three young woodcock, the first reported for Manitoba, was encountered by chance by Eugene F. Bossenmaier. His detailed account of the event (pers. corres., 1975) follows:

"The sighting was made on May 24, 1975 about 4:00 p.m. in a tract of rich, mature, ungrazed aspen forest lying 5 miles north northwest of Reaburn, Manitoba. Clearings - gravel pits, wet meadow adjacent to a bulrush pothole, and a grassy ridge - adjoin the aspen forest. The forest itself consists of open aspen trees with a good shrub understory: willow, highbush cranberry, red osier dogwood and saskatoon, the particular species coinciding with the different moisture regimes within the forest.

"The adult, presumably the hen, flushed about three feet from me as I was moving slowly through some red osier dogwood that lies about 20 feet from the edge of the grassy ridge. Her peculiar flight - body almost perpendicular but parallel to the ground, in a sort of semi-stall - made me suspect a nest. Instead, at my feet, I found 3 downy young, motionless and prostrate. I estimated they were 2-3 days old, about the size of day-old pin-tail ducklings. I did not measure their bill length but on retrospect believe it was about 20 millimeters.

"I handled one of the young and when it was returned to the ground all three began peeping and walking away which brought the adult back in flight. A couple of times it came within 6 feet of me alternating with returning to and landing on the edge of the grassy ridge where it feigned injury. The whole episode from first flushing to my departure from the scene lasted about two minutes."

Reaburn is about 18 miles northeast of Portage la Prairie and 25 miles northwest of Winnipeg. It is an area with extensive grazed and ungrazed aspen and oak woodlands and willow-bordered sloughs. The above brood record may not have been an solated breeding occurrence. Only bix miles to the east a peenting male was observed by B. K. Tully from early March to mid-June, 1976 (pers. cor- res., 1976). This was almost certainly a breeding bird. The following year S. Jonasson heard a bird peenting for two nights in early May, 1977, about a quarter mile away (pers. corres., Tully, 1977).

On June 13 or 14, 1976, Carl Feilberg accidentally drove a vehicle over a newly-hatched woodcock chick, presumably one of a brood, near his home west of East Braintree, an area in which annually a large, resident woodcock population may be found. The behavior of a distraught female called his attention to the dead downy chick. This was on an old logging trail in second growth aspen poplar about two miles southwest of East Braintree. The site was a low spot on an aspen ridge with about eight inches of grass and alders nearby and bordering the edge of an old field; it was damp but not wet.

Willard Anderson and John Pattimore discovered another brood in Birds Hill Provincial Park northeast of Winnipeg on May 12, 1977. In Anderson's words (pers. corres., 1977) ${ }^{13}$ :

"We were walking in the south end of Birds Hill Park in the south part of the loop in an area that was very wet, a fair amount of water on the surface, and largely willow with game-trails bisecting it. I nearly stepped on a female woodcock before she flushed and put on a broken wing act for us. John went to have a closer look at the mature bird and I examined the ground where she was sitting to find two chicks. The chicks were about tennis ball size literally a ball of fluff. Head and back markings were very evident and the two chicks remained very motionless."

The above brood record is supported by sightings in or near Birds Hill Park in recent years, namely one on May 19, 1971 by W. Harris and A. Nijssen (pers. comm., H. W. R. Copland, 1971) and another by $\mathrm{H}$. Stankey on July 15, 1976 (pers. comm., 1976).

In central and southern Ontario woodcock eggs are usually laid in early April. ${ }^{5}$ With an incubation period of 20 to 21 days, the two chicks found at Birds Hill Park must have hatched from eggs laid about April 20-21 (or earlier if they were not newlyhatched). This is supported by the 
Table 1. Woodcock reports from Winnipeg (including Birds Hill Provincial Park area) and localities to the north and west, 1960-77*

$\begin{array}{lllll}\text { Year } & \text { Place } & \text { No. } & \text { Month } & \text { Observer(s) } \\ 1966 & \text { Stonewall area } & 1 & \text { April } & \text { W. Shephard } \\ 1966 & \text { Stonewall area } & 1 & \text { May } & \text { B. D. Stewart } \\ 1967 & \text { Winnipeg } & 1 & \text { September } & \text { Mrs. J. D. Bourns } \\ 1967 & \text { Winnipeg } & 1 & \text { September } & \text { Mrs. N. G. Phillips } \\ 1967 & \text { Winnipeg } & 1 & \text { September } & \text { A. Wittneben, H. Mossop } \\ 1970 & \text { Winnipeg } & 1 & \text { August } & \text { Mr. \& Mrs. R. R. Shearer } \\ 1971 & \text { Birds HillP.P. } & 1 & \text { May } & \text { W. Harris, A. Nijssen } \\ 1974 & \text { Winnipeg } & 1 & \text { April } & \text { L. T. Simmons } \\ 1974 & \text { Hodgson area } & 5 & \text { May-June } & \text { T. Sopuck } \\ 1974 & \text { Gillam } & 1 & \text { June } & \text { D. R. Beckett } \\ 1974 & \text { Winnipeg } & 1 & \text { August } & \text { J. L. Howard } \\ 1975 & \text { Marquette area } & 1 * * & \text { May } & \text { E. F. Bossenmaier } \\ 1976 & \text { Marquette area } & 1 & \text { March-June } & \text { B. K. Tully } \\ 1976 & \text { Delta } & 1 & \text { July } & \text { S. G. Sealy } \\ 1976 & \text { Birds Hill Park area } & 1 & \text { July } & \text { H. Stankey } \\ 1976 & \text { Delta } & 1 & \text { August } & \text { R. Wishart } \\ 1976 & \text { Camper area } & 1 & \text { October (?) } & \text { M. Walker } \\ 1976 & \text { Sandridge } & 6 & \text { October } & \text { D. W. Simkin } \\ 1976 & \text { Winnipeg } & 2 & \text { Sept.-Oct. } & \text { A. W. Scarth } \\ 1977 & \text { Winnipeg } & 1 & \text { April } & \text { L. Logan, L. Hyde } \\ 1977 & \text { Marquette area } & 1 & \text { May } & \text { S. Jonasson } \\ 1977 & \text { Birds Hill P.Park } & 1^{* *} & \text { May } & \text { W. Anderson, J. Pattimore } \\ 1977 & \text { Nopiming Prov. P. } & 1 & \text { May } & \text { C. Cuthbert et al. } \\ 1977 & \text { Delta } & 1 & \text { July } & \text { S. G. Sealy }\end{array}$

*NOTE: Table does not include an abundance of records eastwards of Winnipeg.

**Female with brood.

April 20 egg date at Piney. Even earlier nesting is possible, for woodcock have arrived at Winnipeg as early as March 19. ${ }^{15}$ March and April 1977 were unusually warm and dry months in southern Manitoba.

\section{Migration}

Woodcock winter range is in southeastern United States, in coastal states from New Jersey to eastern Texas, and north to southern Missouri. The bulk of the continental population, however, winters in southeastern Arkansas, Louisiana, and southwestern Mississippi. ${ }^{1}$

Recent research in Minnesota indicates that males and females are believed to arrive together (pers. corres., R. O. Morgenweck, 1977), the males establishing territories where they carry out territorial and courtship displays. Bent notes that: "The woodcock is the first of our waders to migrate north and one of the earliest of all our migrants, com- ing with the bluebirds and the robins, as soon as winter has begun to loosen its grip. The date depends on the weather and is very variable, for the bird must wait for a thaw to unlock its food supply in the bogs and spring holes .... early birds find a living about the big ant hills, until the alder covers (sic) are ready for them."3

Little information is available on arrival dates in Manitoba, but of 43 woodcock observations (1928-1977), 14 are for April, 27 for May. Disregarding the number of birds observed on each date, by mid-May, if not midApril, most woodcock are probably back in the province and on territory. The earliest arrival dates are: one near Marquette "the first week of March", 1976 (B. K. Tully, pers. commun., 1976 1977); one seen in Winnipeg, March 19, 1928 (A. Mount) ${ }^{15}$; and two at Eas1 Braintree, March 24, 1973 (R. W Nero).

The above three dates are probably exceptionally early records, but there is good evidence that all were loca 
resident males. The bird observed by Tully, for example, was heard peenting at least until mid-June; moreover, in the previous year a brood was found not far to the west of that site. Mount's 1928 observation was made in an area where he had frequently seen birds during the past two summers. ${ }^{15}$ Birds were also seen in that area in subsequent summers. My observation on March 24 was of two males, not only peenting but in full aerial display on a known breeding grounds, showing that even earliest arrivals are ready for breeding and competing for territory. The bird that arrived at Marquette in early March had to contend with a foot and a half of snow. The persistence of that individual, which peented nightly despite the deep snow and low temperatures, indicates the hardiness of this species.

Spring migration in Minnesota runs from "late March through early May with a peak in mid-April." Earliest arrival dates in northern Minnesota are March 20 to March $30 .{ }^{11}$

There is good evidence that woodcock may still be migrating here in early May. Late in the evening on May 8, 1976, Herb Copland and I counted 31 peenting woodcock while driving slowly along a 3 mile stretch of highway about 5 miles south of South Junction, just over the border in Minnesota. This is an area where only a few birds were ever found on territory. Owing to the casual method of our survey this would have been a minimal count of the birds in the area.

Because woodcock peent while on migration, records of birds in some localities, especially early in the season, may not indicate residents. Only through repeated visits to a site can prolonged occupancy and, hence, probable breeding be determined.

Movement of birds from breeding grounds in Manitoba may begin in JuPy. A woodcock was captured in a mist net and banded at the University of Manitoba Field Station at Delta Marsh, July 26, 1976; another was flushed in almost the same place on July, 1977 (pers. corres., S. G. Sealy,
1977). (Incidentally, the first woodcock banded in Manitoba was a territorial bird taken in a mist net deliberately set by Herb Copland 5 miles south of Lac du Bonnet on May 22, 1972.) Other Delta Marsh records include one seen by Rick Wishart on August 21, 1976 (pers. corres., 1977), and one seen on May 6, 1948 by Evans and Sowls. ${ }^{36}$ These observations of birds along the Delta Beach ridge may be of local breeding birds or migrants from farther north.

One informant reported to me that a group of people known to him have hunted woodcock somewhere in the Brokenhead River vicinity east of Winnipeg every August for the past several years. He stated that birds were apparently present each year and were believed by these illegal hunters to be local breeding birds. According to Creighton: "As the year progresses, woodcock live in different areas with varying plant life. During courtship and nesting in the spring, they select open fields and young forests. In the summer, they frequent dense alder and shrub thickets. In autumn, they concentrate in damp woodland area, particularly alder swales and poplar tree stands on imperfectly drained sandy loam soils. ${ }^{\prime \prime 5}$

In earlier years, when woodcock were apparently breeding in suburban Winnipeg, autumn records were possibly of local birds that delayed their passage to rest and feed. Such was probably the case for a bird seen in Winnipeg by G. Ferris from midSeptember to October 20, $1934 .{ }^{16}$ On the other hand, the abundance of autumn records, as pointed out by Lawrence, ${ }^{29}$ suggests the occurrence of migrants from elsewhere. Two birds watched almost daily on lawns on the bank of the Red River in Winnipeg from September 29 to October 10, 1976 (pers. corres., A. W. Scarth, 1976) could have come from local or distant populations. One of the latter birds was photographed in color by Alan Scarth.

Of 88 Manitoba sightings, 25 are for September and October. Late dates are: October 17, 1970, one near Shoal 


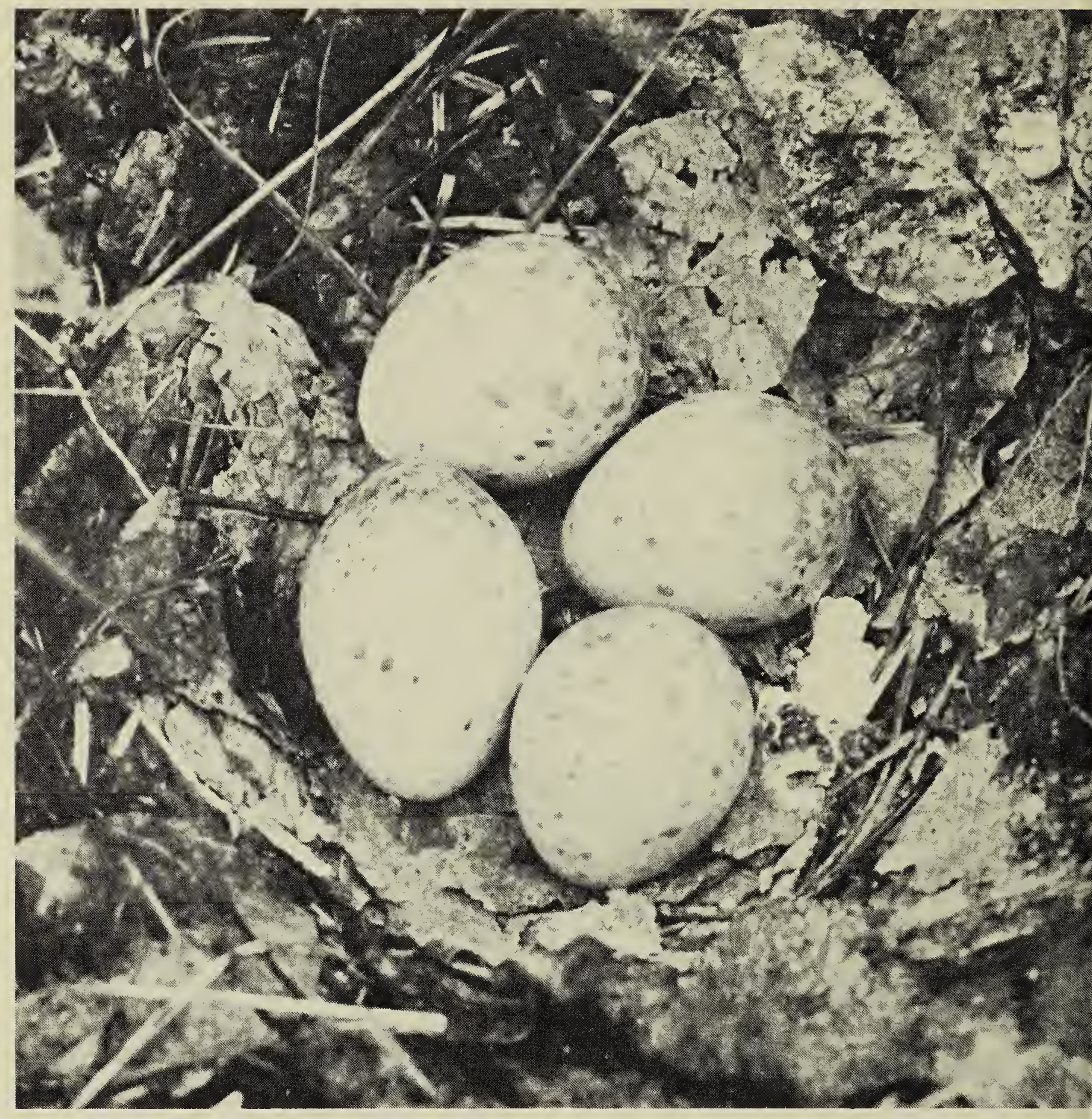

Craig Borcl Woodcock nest. Note the white droppings; this often occurs when a female is frightenec off the nest.

Lake, W. G. Leitch; October 18, 1975, one at Waugh, P. E. Long (pers. corres., W. G. Leitch, 1977); October 19, 1975, one seen near Lewis, south of PR 15 (pers. corres., M. Page); October 20, 1951, an apparent roadkilled specimen from Gardenton (Man. Mus. Man \& Nature). The latest fall date for northern Minnesota is November $2 .{ }^{11}$

\section{Distribution}

Judging by what is now known, woodcock occur regularly as breeding residents south of Lake Winnipeg and east of the Red River; irregularly west to within 50 miles o Winnipeg; and irregularly north tc within 85 miles. The area south and west of Winnipeg, which is mostly in tensively cultivated, may attract fen birds. However, it should be notec that, although it is regarded only as: hypothetical breeding bird in Nort Dakota, there have been severa records in eastern North Dakota, wes of the Red River, including a reportec breeding at Bathgate, 15 mile southwest of Emerson. ${ }^{54}$

An early record of a pair at Antle Creek, in western North Dakota, jus south of the Manitoba-Saskatchewar border, in April, 1923,54 48 indicate 
that this species may occasionally appear in localities beyond their normal range. This is supported by a record for Riding Mountain National Park, September 28, $1933,{ }^{24}$ where none has been observed since, and a report in fall 1960 for the Qu'Appelle valley north of Regina, Saskatchewan. ${ }^{12}$

There remains the possibility that some early records may indicate a fluctuating breeding range, e.g., the A.O.U. states that the woodcock "breeds from southeastern Manitoba ... formerly to eastern North Dakota."2 The Antler Creek, North Dakota, record for 1923 cited above, the five records at Treesbank, Manitoba in 1916 and earlier, ${ }^{16}{ }^{29}$ and the 1908 and earlier records reported for Westbourne and southwest Lake Manitoba, ${ }^{58}$ further suggest the possibility of an occasional temporary extension of range. Mitchell, reporting for this same general period, noted: "No reliable records for the province (Saskatchewan), but its occurrence in south Manitoba and north-east North Dakota would indicate that reports of its apearance at Oxbow and Moose Mountain (in extreme southeastern Saskatchewan) may have some foundation." 40 The number of records in southern Manitoba from 1931 to 1938, as reported by $A$. G. Lawrence (already noted above), may be related to drought conditions.

Observations in even more remote localities have been reported. Tyrrell and Dowling recorded flushing a bird in suitable habitat on August 8, 1892, along the Fond du Lac River west of Black Lake in extreme northeastern Saskatchewan.56 The record was found acceptable by Preble, ${ }^{50}$ and was the basis for a later listing as hypothetical for the region, ${ }^{44}$ and, indeed, for that province. ${ }^{45}$ In Manitoba, R. Bell's record of a single bird at York Factory on Hudson Bay in August, 1879, was accepted by Preble, 49 but in recent years has been disputed. Manning, considered Bell's bird "more likely ... a snipe" ; but Manning flushed two birds "in dry, wooded country at Cape Tatnam" in late August, 1947, that "were believed to be Wilson's Snipe. ... They were not clearly seen, however, and it is just possible that they were woodcock."39 Evidently, Manning, though skeptical of the Bell record, was sufficiently influenced by the latter observation as to leave a suggestion that he himself might have seen woodcock. At this point in time it hardly pays to speculate, but "dry wooded country" sounds more like woodcock than snipe habitat.

A new perspective on these northern reports has been provided by Sheldon who states: "I believe ... that the range should be extended north to northern Ontario and James Bay."51 He then notes that C. H. D. Clarke, in a letter of May 28, 1964, "reports the occurrence of woodcock populations in the James Bay area and farther north. In part Clarke says, 'We have a spring record from the junction of the Ashweig and Winsk rivers just south of Hudson Bay. Farther east the birds are found quite regularly on the way to the southern end of James Bay. There are a few spring records but most of the observations at James Bay have been made during the goose hunting season when woodcock are commonly encountered in the willows along the coast." Sheldon appears convinced that woodcock have long nested in these remote regions, stating: "In the vast wilderness of the North it is possible that woodcock breed in many suitable areas."

That woodcock may nest much farther north in Manitoba than is now suspected is suggested by recent observations by Donald R. Beckett in the Gillam area, 100 miles southwest of York Factory and more than 450 miles north of Winnipeg (Beckett, pers. comm., 1977). ${ }^{7}$ Beckett, who was familiar with woodcock in Port Arthur, Ontario, told me that on June 11,1974 , as recorded in his notes he saw one in typical nuptial flight. This was in late evening and he was able to see the bird flying over the top of some distant trees. He also glimpsed a bird on September 3, 1974, that he thought might have been a woodcock. The particular site where both birds were seen was a sandy ridge 


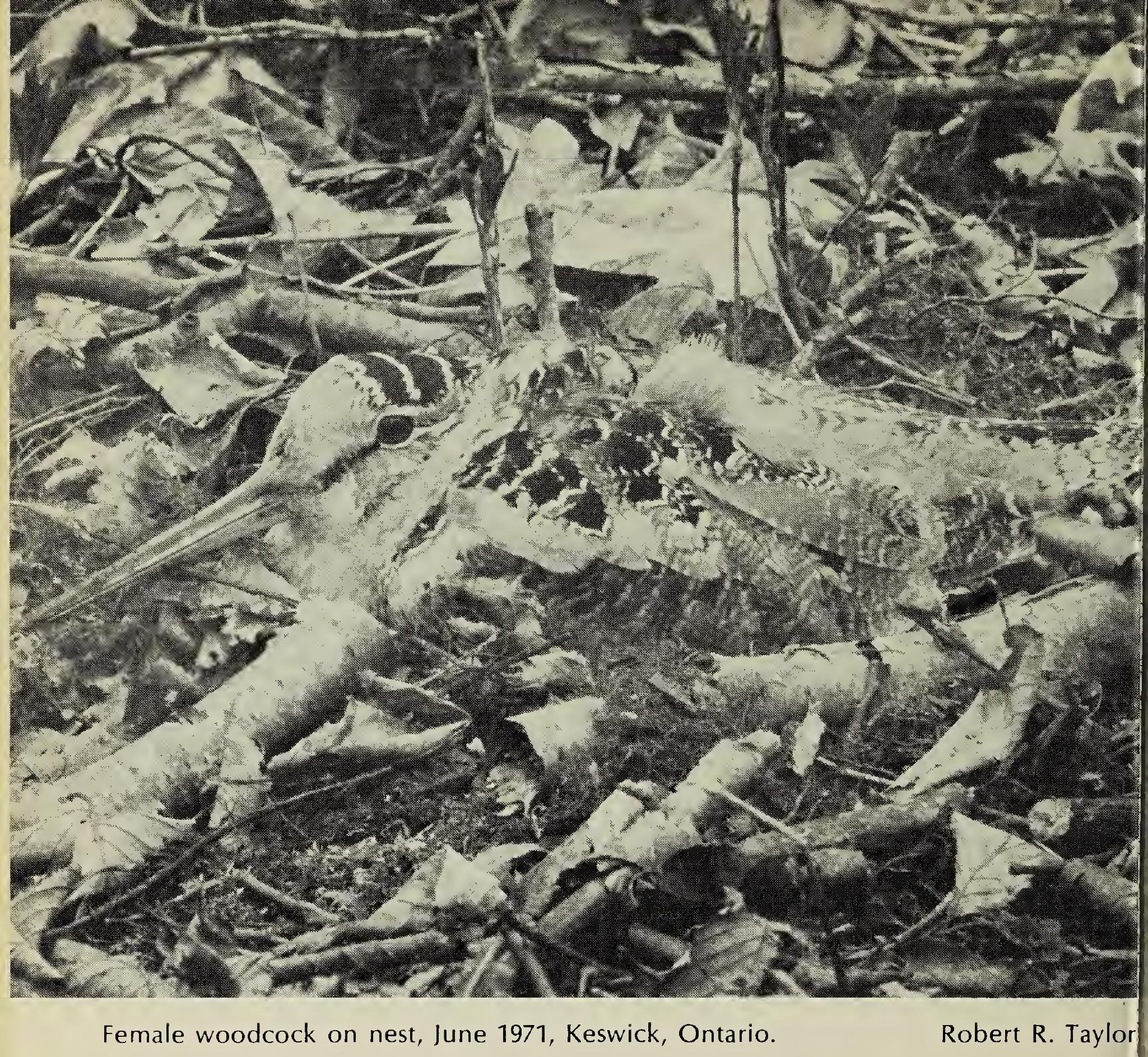

about 8 miles east of Gillam. An old burn, it was relatively open and the site of a gravel pit. Jack pine covered the ridge and provided a screen behind the pit. An adjacent area was covered with willows and alder and was usually damp (see Fig. 3).

There may have been an increased number of woodcock and a range expansion in Manitoba in the 1970's, perhaps similar to that indicated by Lawrence's records for the 1930's. Populations east of Winnipeg apparently are relatively stable, but the appearance of birds to the north and west of that area during the 1970's is in striking contrast to the previous decade. From 1960 to 1969 inclusive, five reports of single birds are available; from 1970 to 1977,19 reports of 25 birds were recorded (see Table 1). Whether these records represent a permanent extension of range or a temporary phenomenon remains to be determined. Temporary expansion at this western extremity of the woodcock's range may be an event of occasional occurrence, perhaps linked to weather or population shifts elsewhere.

In the half century between 1926 and 1977 , woodcock were recorded in metropolitan Winnipeg on at least 34 occasions. In several instances one or more birds were observed repeatedly over several days Although Lawrence comments on the preponderance of fall records, ${ }^{29}$ noted that 24 of the 34 observations were made in spring and summel (March-August) as compared to fal (September-October). The reduced numbers of observations in Winnipe now as compared to earlier times is probably due to a decline in habitat This is likely to continue witt 
development and manicuring of parks and riverbanks. It is of considerable interest to note that the most recent Winnipeg observation, April 10, 1977, by Laurie Logan and Lorne Hyde, was made in Assiniboine Forest, a natural area park of 700 acres.

\section{Habitat and Food Habits}

"Most woodcock are confined to young forest with some scattered openings on poorly drained land. ... The woodcock is a sandpiper that has become adapted to the forest. Its unique physical adaptations and behavior can be explained as adjustments to a habitat remarkable for a shorebird, but it never lost the vestigial requirement for open space for courtship and breeding."

Woodcock breeding grounds require open sites which mav be abandoned fields, old pastures, clearings or even roads and trails where the male performs territorial and courtship displays, and where copulations take place. Generally, the plant succession on the openings is in the early woody stage. Nesting usually takes place within 150 yards of the singing field in a variety of cover, although open, second-growth woodland is preferred. "In the days before colonization, woodcock undoubtedly used natural openings in the forest areas along stream beds, beaver 'meadows', clearings created by fire ..$^{\prime \prime 51}$ Generally, the larger the trees, the larger the size of the opening or singing grounds.

The Manitoba sites where we regularly found woodcock, which were known or believed to be breeding, conform to the above. Most typically, abandoned fields with grassy cover, adjacent to secondgrowth aspen poplar and with some invasion of aspen into the field, predominated. In some cases, willow clumps surrounded or bordered open fields, but the willows backed onto forest stands. Elsewhere, old, clear-cut areas in coniferous or mixed-wood forest stands served as singing grounds. Invariably, alder and birch thickets were found nearby, and often streams or low-lying, damp areas were close. The number of abandoned fields and clear-cut areas in extreme southeastern Manitoba may partly explain the prevalence of woodcock in that area.

In Quebec, Wishart and Bider found a seasonal preference for diurnal habitat: "Upon arrival in the spring, they frequented snow-free areas with warmer microclimate where earthworms would be obtained more easily. When all snow melted, use of mixed and deciduous areas was high compared to that of alder." In autumn, woodcock moved to alder woods, apparently traditional staging areas which "in dry years would supply woodcock with the food requirements for migration. ${ }^{157}$

It may be noted that woodcock breed in greatest densities in the more northern part of their range, reaching a high of 4.01 to 7.00 singing males heard per mile of random route in western Ontario, for example, as compared to 2 to 4 in Wisconsin and up to 1 in Illinois. ${ }^{46}$

With its well known preference for earthworms ("50 to 90 percent of their $\left.\operatorname{diet}^{\prime \prime 53}\right)$, it was inevitable that woodcock would suffer from DDT poisoning. Indeed, woodcock collected in New Brunswick contained so high a level of DDT that no hunting season was permitted there in 1970, and only part of the province was open in $1971 .{ }^{4}$ Since the general ban on DDT, levels in woodcock have decreased.

When earthworms are scarce, woodcock feed readily on other invertebrates, including ants and grasshoppers; lacking animal food, the bird may depend on vegetable material such as fern leaves, ${ }^{3}$ and especially seeds of several plant species. $^{53}$

What woodcock subsist on in Manitoba in March and early April when there is a foot or more of snow on the ground is unknown. It is difficult to imagine a bird finding earthworms or anything edible at that time of year, even on the edge of open streams. It is possible that they 
live off their body fat, or that they eat more plant material than is generally known. It is generally conceded that earthworms (Lumbricus sp.), like bluegrass, were introduced to this continent with the arrival of Europeans. (There are several species of native earthworms, but the abundant and larger Lumbricus species are most widely used as food by woodcock). It is also widely accepted that woodcock seek out feeding sites where earthworms are present, but there is little understanding of the relationship between woodcock breeding sites and settlements or other areas where man has been active, especially in the northern part of its range. Sheldon, in reviewing this aspect of woodcock distribution, points to a relationship between the high rate of nitrogen in litter beneath alders, a condition attractive to earthworms, and the well demonstrated prevalence of alder in woodcock habitat. ${ }^{51}$

\section{Conclusions}

The American Woodcock is and has been for a long time a regular resident of extreme southeastern Manitoba, especially in that area south of Lake Winnipeg and east of the city of Winnipeg. Within that area alone there may be several hundred birds. Land use practices, especially the abandonment of cultivated fields and clear-cutting of timber, may mean that there are more woodcock now than prior to settlement.

How consistent the population of woodcock in extreme southeastern Manitoba is remains to be determined. Similarly, much still is unknown regarding the full extent of its breeding range west and north of Winnipeg, as well as possible fluctuations in range and numbers in that area.

More than offsetting the beneficial land use pratices mentioned above is the conversion of woodcock habitat - wooded and open - to cultivated fields. This may mean a drastic reduction in numbers of woodcock. It may be necessary to take measures to preserve existing occupied habitats or to establish new habitat (and techni- ques for doing this are available) if present populations are to be maintained.

As noted by Sheldon, the woodcock "can continue only so long as we reserve some living space for this ghostlike bird of the uplands. Endowed with fortitude and a certain nobility, the bizarre little American Woodcock excites the wonder of ornithologists and elicits the highest ethics of sportsmen. It is a natural resource of rare quality, offering recreation and aesthetic pleasure to thousands, and one we should be forever vigilant to preserve."

Although there may be insufficient numbers of woodcock in Manitoba to warrant sport hunting, the value of the species for other use is high. The viewpoint expressed by Creighton is especially appealing: "Few people see woodcock because of its secretive nature during most of the summer and its habit of migrating at night in the fall. But there are times of the year when viewing opportunities are available and if the woodcock are concentrated, new and interesting visual and auditory experiences for people can be provided. ${ }^{16}$

\section{Acknowledgements}

I owe a particular debt of gratitude to Herbert W. R. Copland who provided me with all the woodcock information from the numerous columns published by A. G. Lawrence. In addition, Herb was a congenial companion on many of our outings. Herb made several forays by himself in search of woodcock, including one west of Gypsumville and one with Gordon J. Smith to the Vivian Area. Robert R. Taylor kindly offered me his records, and he also accompanied me on several field trips.

I am grateful for the opportunity to publish here for the first time the valuable observation of a brood made by Eugene F. Bossenmaier. His account is an important part of this report. Numerous others have been generous in supplying data, e.g., Willard Anderson, Calvin Cuthbert, 
Jiann and Campbell Elliott, C. Eeilberg, Rod Fowler, Gordon G. Graham, Ken de Graff, Jack L. Howard, William G. Leitch, Phil Ould, Alan W. Scarth, Dr. Spencer G. Sealy, Tim Sopuck, Harold Tirschman and Ray Tuokko. Ken Gardner kindly put ne in touch with Barry K. Tully. Similarly, except for a tip from Dr. vince Crichton, I would not have known about the interesting observations by Don W. Simkin and his companion.

Eugene F. Bossenmaier and Ralph O. Morgenweck read the manuscript and offered helpful comments. Ed ohrenz kindly prepared the maps. Robert R. Taylor, always helpful, provided the photograph of the woodcock.

References below not mentioned in the text contributed data for the maps.)

\section{'AMERICAN ORNITHOLOGISTS'}

UNION. 1957. Check-list of North American birds. 5th ed. Lord Baltimore Press, Baltimore, Maryland. 691 pp.

${ }^{2} \mathrm{BEIGHTOL}, \mathrm{D} . \mathrm{R}_{.}$, and D. E. SAMUEL. 1973. Sonagraphic analysis of the American Woodcock's peent call. J. Wildl. Manage. 37:470-475

${ }^{3}$ BENT, A. C. 1927. Life histories of North American shore birds. U.S. Natl. Mus. Bull. 142, Part 1 (reprinted by Dover Publ., Inc.).

${ }^{4} \mathrm{COOCH}, \mathrm{F}$. G. 1976 . Kill of migratory game birds other than waterfowl by hunters in Canada 1975. Can. Wildl. Service, Progress Notes No. 68, 7 pp.

${ }^{5}$ CREIGHTON, W. A. 1972a. Where to find Woodcock in Ontario. Ontario Fish and Wildlife Review 11:11-14.

${ }^{6}$ CREIGHTON, W.A. 1972b. Past, present and future woodcock management in Ontario. Ministry of Natural Resources, Mimeo. Rep. 5 pp \& 11 tables.

'DIDIUK, A. B. 1975. Fish and wildlife resources impact assessment, Lower Churchill River, Manitoba. Dept. Mines, Resources and Environmental Mgt., Research Bn., Winnipeg, $216 \mathrm{pp}$.

${ }^{8}$ GARDNER, K. 1970. "Wild Wings" Winnipeg Tribune. August 29, 1970.
${ }^{9}$ GOATCHER, M. 1975. Manitoba legislation affecting wildlife from 18761972. Man. Dept. Mines, Resources and Environmental Mgt., 111 pp., mimeo.

${ }^{10}$ GODFREY, W. E. 1966 . The birds of Canada. Natl. Mus. Can. Bull. No. 203, Biol. Series No. 73. 428 pp \& 69 plates, 2 maps.

${ }^{11}$ GREEN, J. C., and R.B. JANSSEN. 1975. Minnesota birds, where, when and how many. Univ. of Minn. Press, Minneapolis. 217 pp.

${ }^{12}$ HARRISON, S. 1960. Woodcock sighted in the Qu'Appelle valley. Blue Jay 18:160.

${ }^{13} \mathrm{HATCH}$, D. 1977. "Chickadee Notes" 172. Winnipeg Free Press, June 18, 1977.

${ }^{14}$ LAWRENCE, A. G. 1923. "Chickadee Notes" 134. Wpg. Free Press, Oct. 18, 1923.

${ }^{15}$ LAWRENCE, A. G. 1928a. "Chickadee Notes" 368. Wpg. Free Press, April 12, 1928.

${ }^{16}$ LAWRENCE, A. G. 1928b. "Chickadee Notes" 377. Wpg. Free Press, June 14, 1928.

${ }^{17}$ LAWRENCE, A. G. 1929. "Chickadee Notes" 447. Wpg. Free Press, Oct. 17, 1929.

${ }^{18}$ LAWRENCE, A. G. 1931a. "Chickadee Notes" 548. Wpg. Free Press, Sept. 25, 1931.

${ }^{19}$ LAWRENCE, A. G. 1931b. "Chickadee Notes" 561. Wpg. Free Press, Dec. 1931.

${ }^{20}$ LAWRENCE， A. G. 1932a. "Chickadee Notes" 579. Wpg. Free Press, April 29, 1932.

${ }^{21}$ LAWRENCE, A. G. 1932b. "Chickadee Notes" 605. Wpg. Free Press, Oct. 28, 1932.

${ }^{22}$ LAWRENCE, A. G. 1933a. "Chickadee Notes" 632. Wpg. Free Press, May 5, 1933.

${ }^{23}$ LAWRENCE, A. G. 1933b. "Chickadee Notes" 652. Wpg. Free Press, Sept. 22, 1933.

${ }^{24}$ LAWRENCE, A. G. 1933c. "Chickadee Notes" 654. Wpg. Free Press, Oct. 6, 1933.

${ }^{25}$ LAWRENCE, A. G. 1934a. "Chickadee Notes" 712. Wpg. Free Press, Nov. 16, 1934.

${ }^{26}$ LAWRENCE, A. G. 1934b. "Chickadee Notes" 713. Wpg. Free Press, Nov. 23, 1934. 
${ }^{27}$ LAWRENCE, A. G. 1934C. "Chickadee Notes" 718. Wpg. Free Press, Dec. 28, 1934.

${ }^{28}$ LAWRENCE, A. G. 1936. "Chickadee Notes" 802. Wpg. Free Press, Aug. 7, 1936.

${ }^{29}$ LAWRENCE, A. G. 1937a. "Chickadee Notes" 829. Wpg. Free Press, Feb. $12,1937$.

${ }^{30}$ LAWRENCE, A. G. 1937b. "Chickadee Notes" 831. Wpg. Free Press, Feb. 26, 1937.

${ }^{31}$ LAWRENCE, A. G. 1937c. "Chickadee Notes" 839. Wpg. Free Press, April 23, 1937.

32.LAWRENCE, A. G. 1938. "Chickadee Notes" 895. Wpg. Free Press, May 20, 1938.

${ }^{33}$ LAWRENCE, A. G. 1944. "Chickadee Notes" 1225. Wpg. Free Press, Sept. 15, 1944.

${ }^{34}$ LAWRENCE, A. G. 1945. "Chickadee Notes" 1258. Wpg. Free Press, May 4, 1945.

${ }^{35}$ LAWRENCE, A. G. 1946. "Chickadee Notes" 1306. Wpg. Free Press, May 31, 1946.

${ }^{36}$ LAWRENCE, A.G. 1948. "Chickadee Notes" 1409. Wpg. Free Press, May 21, 1948.

${ }^{37}$ LAWRENCE， A. G. 1949. "Chickadee Notes" 1462. Wpg. Free Press, May 27, 1949.

${ }^{38}$ LAWRENCE, A. G. 1950. "Chickadee Notes" 1512. Wpg. Free Press, May 12, 1950.

${ }^{39}$ MANNING, T. H. 1952. Birds of the west James Bay land southern Hudson Bay coasts. Natl. Mus. Can. Bull. No. 125.114 pp.

${ }^{40}$ MITCHELL, H. H. 1924. Birds of Saskatchewan. Can. Field-Nat. 38:101-118

${ }^{41}$ MOSSOP, H. 1966a. "Chickadee Notes" 591. Wpg. Free Press. May 14, 1966.

${ }^{42}$ MOSSOP, H. 1966b. "Chickadee Notes" 594. Wpg. Free Press. June 4, 1966.

${ }^{43}$ MOSSOP, H. 1967. "Chickadee Notes" 660. Wpg. Free Press. Sept. 23, 1967.

${ }^{44 N E R O, ~ R . ~ W . ~ 1963 . ~ B i r d s ~ o f ~ t h e ~ L a k e ~}$ Athabasca region, Saskatchewan. Spec. Pub. 5, Sask. Nat. Hist. Soc., Regina. 143 pp.

${ }^{45}$ NERO, R. W., and M. R. LEIN. 1971. Birds of Moose Mountain, Saskatchewan. Spec. Publ. 7, Sask. Nat. Hist. Soc., Regina, 55 pp.
${ }^{46}$ OWEN, R. B. Jr. 1977. American Woodcock. Pages 149-186 in G. B. Sanderson, ed. Management of migratory shore and upland game birds in North America. Inter. Assoc. Fish and Wildlife Agencies, Washington, D.C.

${ }^{47}$ PALLISER, T. 1860-63. Exploration - British North America. The journals, detailed reports, and observations relative to the exploration. G. E. Eyre and W. Spottiswoode, London

${ }^{48}$ PETTINGILL, O. S., J. R. 1936. The American Woodcock. Philohela minor (Gmelin). Mem. Boston Soc. Nat. Hist. 9: 169-391

${ }^{49}$ PREBLE, E. A. 1902. A biological investigation of the Hudson Bay region. N. Amer. Fauna No. 22, U.S. Dept. Agric., Div. Biol. Surv. 140 pp \& map.

${ }^{50}$ PREBLE, E. A. 1908. A biological investigation of the AthabaskaMackenzie region. U.S. Bur. Biol. Surv., N. Amer. Fauna No. 27, $574 \mathrm{pp}$

${ }^{51}$ SHELDON, W. G. 1967. The book of the American Woodcock. Univ. Mass. Press, Amherst, Mass. $x$ vii \& $277 p p$

${ }^{52}$ SHORTT, A. 1969. "Wild Wings" Winnipeg Tribune. May 9, 1959.

53SPERRY, C. C. 1940. Food habits of a group of shorebirds: Woodcock, snipe, knot and dowitcher. U.S. Biol. Survey. Wildlife Research Bull. 1. 37 pp. (Not seen).

${ }^{54}$ STEWART, R. E. 1975 . Breeding birds of North Dakota. Tri-college center for Environmental Studies, Fargo, North Dakota. 295 pp.

${ }^{55}$ THOMPSON, E. E. (E. T. SETON) 1891. The birds of Manitoba Proc. U.S. Natl. Mus.,

13:457-643. (Reprinted, Premium Ventures, Ltd., Winnipeg. 1975).

${ }^{56}$ TYRRELL, J. B., and D. B. Dowling 1896. Report on the country between Athabasca Lake and Churchill River Geol. Surv. Can., Ann. Rep. 1895 (New Series), 8 (Rep. d):5-120

${ }^{58}$ WISHART, R. A., and J. R. BIDER 1977. Aspects of woodcock nocturna activity in southwestern Quebec Can. Field Nat. 91:141-147.

${ }^{58}$ WALLIS, J. B. 1908 . The occurrence of the American Woodcock (Phil ohela minor) in Manitoba. Ottawa Nat. 22:186-187. 